\title{
Flexibility of the Labour Market
}

\author{
Frank Cörvers · Rob Euwals · Andries de Grip
}

Published online: 4 January 2012

(C) Springer Science+Business Media, LLC. 2011

\section{Introduction}

The flexibility of European labour markets remains an important topic. At the policy level, there is a call for more labour market flexibility as globalisation and technological and organisational change are major drives of accelerated change in the economic environment. Furthermore, the ageing of the workforce may weaken its adaptability to labour market shocks because retraining and mobility are less profitable for older workers. Employers seem to react to such developments by becoming more hesitant to hire permanent workers for jobs which need little investments in skills and knowledge. Instead, they hire temporary workers in order to be able to absorb shocks in labour demand. The incidence of temporary employment is already high in countries such as Spain and Portugal, and now it is also at a rise in a country such as the Netherlands, where it according to OECD data increased from $11 \%$ of dependent employment in 1995 to almost $19 \%$ in 2010.

At the societal level, labour market flexibility leads to concerns as to duality of the labour market. This duality may lead to inequality between core workers with permanent contracts and those with other contracts. The inequality is particularly related to bearing the burden of economic shocks and different opportunities to benefit from firms' investments in the skills and knowledge of their workers. This will be less a

\footnotetext{
F. Cörvers · A. de Grip

Research Centre for Education and the Labour Market (ROA), Maastricht University, Maastricht, The Netherlands

R. Euwals $(\square)$

CPB Netherlands Bureau for Economic Policy Analysis, The Hague, The Netherlands

e-mail: r.w.euwals@cpb.nl

R. Euwals · A. de Grip

IZA, Bonn, Germany
} 


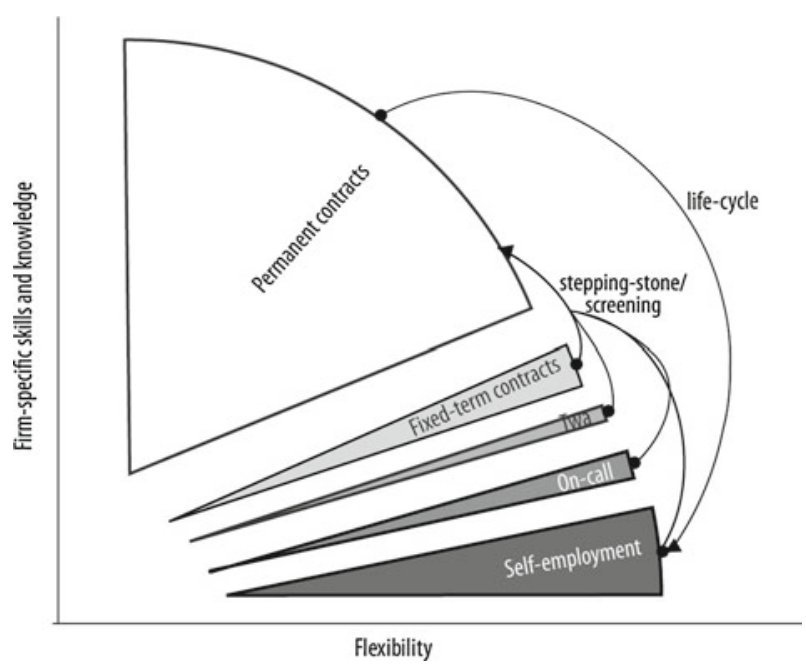

Fig. 1 Permanent and flexible labour contracts in the Netherlands. Note The size of each slice represents the share in the Dutch workforce. A permanent contract mostly implies a high level of firm-specific skills and knowledge, and a low level of flexibility. Many workers start employment with a flexible contract, move on to a permanent contract (stepping stone/screening) and later in life self-employment becomes more important

problem when flexible labour contracts are stepping stones for permanent contracts. However, duality becomes more severe when there is low mobility towards permanent contracts for those who are in search for such a contract.

This special issue focuses on the role of the different types of labour relations on the labour market: the permanent contract and the different types of flexible contracts. The volume discusses issues like the protection of permanent and temporary jobs, the adaptability of the economy, investments in skills and knowledge and workers' wages.

\section{General Framework}

Most European labour markets distinguish one type of permanent contract and various types of flexible contracts. The coexistence of permanent and flexible labour contracts makes sense from an economic point of view, since they serve different goals. Figure 1 summarizes the relation between the flexibility of a type of contract, the level of human capital investments and the mobility between the types of contracts.

Most workers on the Dutch labour market have a permanent contract as the size of the upper slice in Fig. 1 represents. Such a contract does not include a date or condition upon which the contract ends. In most European countries, an employer can only dismiss a worker against his will if specific conditions are met, while a worker merely needs to take a term of notice into account in case he wants to leave the firm. As a result, the contract offers little flexibility to employers to adjust the size of their workforce to temporary and structural changes in the demand for their products or services. However, permanent contracts may act as a commitment device for both workers and 
firm to invest in human capital for types of work which need such investments. In this way, permanent contracts enable firms to adapt their workforce to changes in skill requirements due to technological and organisational changes, without the fear that their workers are searching for another job continuously. In particular firm-specific training investments paid by the employer may further increase the commitment between the worker and the firm.

Flexible contracts, on the other hand, offer flexibility by allowing firms to adjust the size of their workforce to changes in the economic environment. Many European countries distinguish several types of flexible contracts, including fixed-term contracts, on-call contracts and temporary work agency contracts. A fixed-term contract includes a date or condition upon which the contract automatically ends. An on-call contract implies the worker only works in case the employer is in need of labour. Employment through a temporary work agency is strictly defined by legal rules in most European countries. The worker has an employment contract with the agency but works under the authority of the firm which hires the worker from the agency. Apart from the opportunity to adjust the size of the workforce without any delay, fixed-term contracts and temporary work agency contracts allow firms to learn about the quality of newly recruited workers and offer individuals opportunities to search for the right job. Over time, temporary workers may move on to permanent jobs. Such aspects may compensate individual workers for the uncertainty of some types of temporary contracts resulting in a job satisfaction that is not lower than for workers with a permanent contract. The level of human capital investments in workers with flexible contracts are low, however, and only for university graduates there are indications that flexible contracts may provide stepping stones to permanent contracts.

\section{The Papers in This Special Issue}

The first contribution to this special issue, by John Martin and Stefanno Scarpetta, addresses the links between employment protection legislation, labour reallocation and productivity growth. Martin and Scarpetta argue that stringent employment protection has a sizeable negative effect on labour market flows and, through this channel, hinders productivity growth. At the same time, evidence also shows that while a larger labour market reallocation benefits many workers through higher wages and more career opportunities, some displaced workers are worse off because of longer unemployment durations and lower real wages in post-displacement jobs.

The second contribution, by Torben Andersen, discusses the response of the Danish labour market to the economic crisis in the years 2008 and 2009. The Danish labour market is often seen as the classical example of the flexicurity model, with flexible hiring and firing rules, a generous social safety net, and active labour market policies. On the basis of international comparative evidence, Anderson concludes that the Danish employment adjustment has not been particularly large and that the flexicurity model is not more prone to persistence than other alternative models. The level of job creation remains high despite the crisis, although job creation is of course pro-cyclical 
and job-separation counter-cyclical. The larger inflow into activation schemes makes it a challenge to maintain the efficiency of the system in an environment with high unemployment.

The next contributions in this volume focus on the Dutch labour market. The Dutch labour market is characterized by one of the lowest unemployment rates of the OECD countries and also by a mild increase in this rate in response to the economic crisis. Nevertheless, there are serious concerns in the Netherlands about the high average unemployment duration and the relatively low job mobility for in particular older workers.

Anja Deelen investigates the role of wage-tenure profiles in explaining patterns of job mobility. The results suggest that wage-tenure profiles in the Netherlands are relatively steep compared to other countries. The seniority position of a worker turns out to increase wages, whereby the size of the impact is not particularly large. Furthermore, industries with high returns to tenure appear to have high shares of older workers, as well as high average job tenure. This implies that steep wage-tenure profiles are related to low levels of job mobility.

Daniëlle Bertrand-Cloodt, Frank Cörvers, Ben Kriechel and Jesper van Thor focus on the labour market position of recent graduates, who typically have a high incidence of entering into flexible contracts. Graduates with flexible contracts face large wage penalties, worse job matches, and less training participation than those with permanent contracts. When the labour market situation for a particular field of education deteriorates, a larger share of recent graduates accepts a flexible contract. However, flexible work among graduates is unrelated to their willingness to take risks. Only for university graduates flexible contracts may serve as a stepping stone to a permanent contract.

Didier Fouarge, Andries de Grip, Wendy Smits and Robert de Vries focus on differences in human capital investments between workers with flexible contracts and those with a permanent contract. Workers with flexible contracts participate less often in training than those with permanent contracts, and they participate in particular less often in employer-funded training that is meant to keep up with new skill demands in the job. The lower training participation of flexworkers is likely to impede the workers' adaptability to changing skill demands in the labour market. However, a flexible contract appears to facilitate the transition to a permanent contract with the same employer for those who participate in employer-funded firm-specific training.

Marloes de Graaf-Zijl investigates job satisfaction as an aggregate of a worker's satisfaction with several job aspects. The estimation results indicate that temporary agency work is the only flexible labour relation that is associated with lower job satisfaction compared to workers with a permanent labour relation. A major part of the gap in job satisfaction is due to the low satisfaction experienced by agency workers regarding the content of their job, while a lack of job security also plays a role. For fixed-term and on-call workers the negative satisfaction effect originating from the lack of job security and lower wages appears to be compensated by other job aspects. 


\section{Lessons for Policy}

One of the foremost concerns for policy makers is that a sharp distinction between permanent and flexible contracts may lead to duality and inequality on the labour market. Permanent contracts serve as a commitment device for workers and firms to invest in human capital. On the other hand, flexible contracts may offer opportunities to firms to adjust the size of their workforce to temporary and structural changes in the demand for their products or services. These contracts also offer both firms and workers an opportunity to learn about various aspects of the job-worker match. Furthermore, flexible contracts lower the thresholds to employ workers with uncertain productivity. However, for some workers a flexible contract seems not really attractive as wages and investments in skills and knowledge are clearly low compared to workers with a permanent contract. This particularly holds when flexible contracts do not serve as steppingstones to permanent contracts. Labour market reforms to address the protection and opportunities of workers with flexible contracts should, however, be part of a comprehensive package that addresses the legal rules of flexible and permanent contracts simultaneously.

Two extreme options for reducing the distinction between flexible and permanent jobs can be distinguished: an increase in the protection and rights of workers with a flexible contract or a decrease in the protection and rights of workers with a permanent contract. A combination of the two options may mitigate the unfavourable outcomes of the two options.

The first policy option will mitigate the inequality among workers, but not necessarily within the entire labour force. Part of the workers with unclear productivity may become unemployed because firm may not take the risk to recruit them. Moreover, firms will hire fewer flexible workers and so they will have fewer opportunities to adjust the size of their workforce in booms and busts. So although some workers with a flexible contract may be better off, others may actually be worse off.

The second policy option will lead to less inequality among workers and may induce firms to hire more permanent workers. Lowering the protection of permanent jobs will give firms more flexibility to adjust their workforce to business cycle fluctuations or technological and organizational changes. This may lead to more economic growth and job opportunities. The recent experience of the Danish flexicurity model shows that displaced workers still face job opportunities as the level of job creation remains high during an economic downturn. Nevertheless such a reform will be at the expense of workers with a permanent contract as they will experience less job security. This may lead to lower mutual commitment of workers and firms leading to lower provision of effort as well as lower investments in human capital. Furthermore, some displaced workers may lose out because of longer unemployment durations or lower real wages in post-displacement jobs. For these reasons, reforms on the protection of permanent contracts should be considered as part of a comprehensive package that keeps the functioning of such contracts for mutual commitment in place and additionally includes an adequate safety net for the unemployed and effective re-employment services. 